University of Warwick institutional repository: http://go.warwick.ac.uk/wrap This paper is made available online in accordance with publisher policies. Please scroll down to view the document itself. Please refer to the repository record for this item and our policy information available from the repository home page for further information.

To see the final version of this paper please visit the publisher's website. Access to the published version may require a subscription.

\author{
Author(s): Oswald, Andrew \\ Article Title: An Economist's View of University League Tables \\ Year of publication: 2001 \\ Link to published version: http://dx.doi.org/10.1111/1467-9302.00265 \\ Publisher statement: The definitive version is available at \\ www.blackwell-synergy.com
}




\title{
An Economist's View of University League Tables
}

\author{
May 2001 \\ Andrew Oswald, Professor of Economics, University of Warwick
}

Many newspapers and magazines now publish league tables of universities. They do this because it sells extra copies of their publications. All over the world, school-teachers pin these tables up on notice-boards.

Human beings are fascinated by rankings. It is presumably for Darwinian reasons: your many-times great grandfather came high up a pecking order and that is why you are still here. Even in games, like football or table tennis, people have to construct leagues.

Economists have a generic view: most of the time if you allow people to be free the world will come out well. How does that do in the case of university league tables? My view is: poorly. This is a case, like pollution from a smoky factory, where private actions cause bad 'externalities' on others.

The main issue, here and throughout much of what we have seen in public sector regulation in the last decade, is what might be described as the conflict between informing the consumers and disheartening the employees.

Say we take the Financial Times league table of universities. It rates 97 universities on a set of 16 criteria. These are the average A-level scores of the entering students, the ratio of applications to places, the staff-student ratio, research quality as assessed by the government Research Assessment Exercise, teaching quality as measured by the of Quality Assurance Agency, percentage of first class degrees, the employment rate of leaving students, percentage of students entering professional training, percentage of graduates going on to a higher degree, percentages of students going into research degrees and taught masters degrees, percentage of overseas students, per-capita 
university income from industry, research grant income per capita, computer expenditure per capita, and library expenditure per capita. It sums the outcomes from these criteria, assigns weights without explaining how it chooses those, and publishes a league table. In its most recent table, the University of Cambridge came top and the University of Paisley came bottom.

Point 1. University league tables use a method that would not be tolerated by journalists to create a league table of newspapers.

The reason is that things of marginal significance are given a large weight. If we were to rate newspapers in a league table, it might be natural to put $80 \%$ weight on the quality of the writing, and let the other $20 \%$ be determined by an assortment of things such as type of font, use of colour, the attractiveness of adverts, delivery lags, and so on. But this is not what happens with university league tables. Research and teaching - the main functions of a university - are in combination given only about $25 \%$ of the weight in the normal league table. At best, this is strange. At worst, it is absurd.

Point 2. University league tables are currently of little use to policymakers because they reveal nothing about efficiency.

For example in 2001, according to the FT, Oxford had the single largest spending per student on libraries: 1100 pounds per-capita compared to a norm for British universities of about 300 pounds. From the economist's point of view, society needs to know where it is getting the biggest bang for its library buck. For a given quality of research and teaching, universities should be congratulated if they use few resources. That is what efficiency means. Yet university league tables reward the opposite.

Point 3. The people who actually work in universities, the academics, would not rank universities in the way done by newspapers.

For hundreds of years, the quality of a person's research has been the over-riding criterion for promotion and hiring. Those outside universities often find this puzzling or worse. Yet the norm has grown up not because of any conspiracy or mistake. Rather, universities through the ages have learned that the contribution of a scholar is 
mainly through the ideas that he or she leaves in the minds of the next generation. British citizens and politicians never think to ask: where do the ideas in high school textbooks actually come from? The answer, though, is from universities. One of my friends hardly sees a student, but he will be one of the most important teachers that British economics has ever produced - when his ideas reach the textbooks that your grandchildren will read at age 15 .

Point 4. League tables create perverse incentives.

For example, universities now feel under pressure to give more and more Firsts. Yet it is advisable for a society to give its institutions of higher education the incentive to set tough standards.

Point 5. There is a serious problem in Britain caused by the disheartening effects of university league tables.

How would you feel about working in Britain's $94^{\text {th }}$ best university? It is unlikely that, for teams, there is a sports league table anywhere in the world with 100 members. My research on stress and job satisfaction in the public sector* has found a marked deterioration in mental wellbeing through the 1990s. This is true generally, not merely in the education sector. Although I am not yet able to construct a formal test, my judgment is that much of this fall in morale in the public sector is because of what might be termed the public humiliation that has been a feature of the 1990s.

Human beings are ill-equipped to deal with low status. People draw selectively on evidence around them to build comforting ways of viewing themselves and what they do. According to surveys, there is barely a man in England who is much less than 6 feet tall. This is human; it is not to be looked down upon.

Efficiency is important. But we have little idea what happens to public sector workers when these psychological defence mechanisms are taken away. Politicians who advocate the use of naming and shaming do not seem to have noticed that it is not done in the bastion of efficiency: the private sector. If you work for BT as a manager, your job performance is carefully evaluated and you have many meetings with your boss to discuss how you are doing. But the 
results are not published in the local newspaper for your neighbours to read. If we are to have good people in our public-sector, the jobs have to be attractive. That has been forgotten.

Where might university league tables go next? Academics rate universities virtually entirely by their research. Students rate universities largely by whether they will have an enjoyable experience there. Parents rate universities by the employability they produce in their offspring, the safety of the campus, and the status that the university buys them.

Britain needs a wider range of rankings. My view is that, as in the United States, pressures will grow to create diversity and subleagues. Hence I expect to see the British newspapers of the future publish three or four leagues within their Good Universities special issue. It is not sensible to rank Cambridge and Paisley within one table. They have different tasks and should be judged with that it mind. It is a particular mistake for our country to leave the students and staff of Paisley feeling bad about themselves; their contribution to society is large. I also expect to see a move to the ranking of smaller units such as all of the British departments of economics or classics. Such rankings would be more useful to students (as one or two newspapers are starting to recognise). Averaging across pineapples and grapes does not make sense.

We have to be realistic. These kinds of rankings, in some form, are here to stay. Britain is a free country and newspapers can publish what they wish. But I believe that university league tables currently do more harm than good.

- "What Has Been Happening to Job Satisfaction in Britain?" By Jonathan Gardner and Andrew Oswald, March 2001, downloadable from www.oswald.co.uk

I thank Paul Greatrix of Warwick University for helpful suggestions, but am solely responsible for the opinions expressed here. 